\title{
PERKEMBANGAN EKONOMI SUBSEKTOR PERIKANAN DI KABUPATEN MINAHASA SELATAN PROVINSI SULAWESI UTARA ${ }^{1}$
}

\author{
Economic Development Fisheries Subsector in the South Minahasa Regency
}

\author{
Aldy Adrianus Tatali ${ }^{2}$, Eddy Mantjoro ${ }^{3}$, Florence V Longdong ${ }^{3}$
}

\begin{abstract}
The Development of fisheries in North Sulawesi refers to fisheries subsector progress and national marine. Also look at the potential of natural resources, so that fisheries and marine sector to be one of the flagship program of economic development of North Sulawesi. By knowing the great potential of fisheries resources and the development of fishing effort, aquaculture and fisheries management efforts, the government set the fisheries subsector as one driving force of development. Fishermen fishing in coastal South Minahasa regency fishing along the coast and in the Celebes Sea. Most fishermen only catch about 2-3 miles away from the coast. For fishermen purse seine at a distance far enough from the coast 7-12 mill. Mariculture potential to be developed because it is supported by the marine and coastal areas of South Minahasa regency broad and potent. Some commodities, seeded mariculture in South Minahasa Regency is seaweed, grouper, giant travelly (bobara) and sea cucumbers. Production of processed fishery products in South Minahasa Regency is very diverse both in the traditional and modern though. Commodities processed fishery products in the form of wooden fish, salted fish, smoked fish/fufu and bakasang.
\end{abstract}

Keywords : economic, development, fisheries

\section{ABSTRAK}

Pengembangan usaha perikanan di Sulawesi Utara mengacu pada pembangunan subsektor perikanan dan kelautan nasional. Juga melihat potensi sumberdaya alam, sehingga dari sektor perikanan dan kelautan menjadi salah satu program unggulan pembangunan ekonomi Sulawesi Utara. Dengan mengetahui potensi sumberdaya perikanan yang besar dan perkembangan usaha penangkapan, budidaya dan usaha pengelolaan hasil perikanan maka pemerintah menetapkan subsektor perikanan sebagai salah satu motor penggerak pembangunan. Nelayan perikanan tangkap di pesisir Kabupaten Minahasa Selatan menangkap ikan sepanjang pantai maupun di Laut Sulawesi. Kebanyakan nelayan tradisional hanya menangkap ikan sekitar 2-3 mil jauhnya dari pantai. Bagi nelayan Purse Sein cukup jauh dengan jarak 7-12 mill dari pantai. Budidaya laut sangat potensial untuk dikembangkan karena di dukung oleh wilayah laut dan pesisir Kabupaten Minahasa Selatan yang luas dan potensial. Beberapa komoditi yang menjadi unggulan budidaya laut di Kabupaten Minahasa Selatan adalah rumput laut, ikan kerapu, ikan kuwe (bobara) dan teripang. Produksi olahan hasil perikanan di Kabupaten Minahasa Selatan sangat beragam baik yang di olah secara tradisonal maupun modern. Komoditas olahan hasil perikanan itu berupa ikan kayu, ikan asin, ikan asap/fufu dan bakasang.

Kata kunci : ekonomi, pengembangan, perikanan

\footnotetext{
${ }^{1}$ Bagian dari skripsi

${ }^{2}$ Mahasiswa Program Studi Agrobisnis Perikanan FPIK-UNSRAT

${ }^{3}$ Staf pengajar Fakultas Perikanan dan IImu Kelautan Universitas Sam Ratulangi
} 


\section{PENDAHULUAN}

Sebagai wilayah yang belum lama dimekarkan, Kabupaten Minahasa Selatan terus berusaha mengembangkan perekonomian wilayah dengan dukungan potensi sumber daya alam yang dimilikinya sebagai usaha meningkatkan perekonomian daerah. Perikanan masuk kedalam sub-sektor industri primer dengan tugas pokok menyediakan bahan makanan sebagai kebutuhan dasar masyarakat Minahasa Selatan.

Tujuan yang ingin dicapai melalui penelitian ini adalah: (1). mengumpulkan data tentang keadaan lokasi penelitian; (2). menyediakan data dan menganalisa tingkat perkembangan sumberdaya pesisir; (3). menyediakan data dan menganalisa perkembangan sumberdayamanusia; (4). menyediakan data perkembangan sumberdaya perikanan; (5). menyediakan data perikanan tangkap di Kabupaten Minahasa Selatan; (6). menyediakan dan menganalisa data budidaya perikanan; (7). Menyediakan data pengolahan produk perikanan; (8). Menyediakan data perkembangan usaha perikanan

Penelitian ini diharapkan dapat mendatangkan manfaat bagi peneliti, bagi masyarakat akademis dan juga bagi masyarakat. Beberapa manfaat yang diharapkan timbul dari penelitian adalah : (1). Bagi ilmu sosial ekonomi untuk mendapatkan tambahan pengetahuan khususnya yang terkait ekonomi sumber daya perikanan; (2). Bagi peneliti memberikan tambahan pengalaman sebagai dasar melakukan penelitian selanjutnya; (3). Bagi peneliti lain sebagai sumber informasi tentang masalah yang dapat diteliti lebih lanjut.

\section{METODE}

\section{Dasar Penelitian}

Dasar penelitian ini adalah metode penelitian survei untuk melihat perkembangan perekonomian di bidang perikanan dan menginventarisir usaha perikanan yang berkembang di Kabupaten Minahasa Selatan,.

$$
\begin{gathered}
\text { Pengambilan data dilakukan } \\
\text { dengan metode survei untuk }
\end{gathered}
$$
menentukan status populasi pada waktu dilakukan penelitian (Sumanto dalam De'e, 2010). Untuk mengambil sampel dilakukan dengan metode random sampling di mana semua individu dalam populasi baik secara sendiri-sendiri atau bersama diberi kesempatan yang sama untuk di pilih menjadi anggota sampel (Nurboko dan Achmadi, 2005). Metode penelitian ini bertujuan untuk mempermudah peneliti dalam pengambilan data langsung ke lokasi para nelayan dan para pengusaha perikanan di Kabupaten Minahasa Selatan.

\section{Tempat dan Waktu Penelitian}

Penelitian dilaksanakan di wilayah Kabupaten Minahasa Selatan. Waktu yang di perlukan untuk melaksanakan penelitian mulai dari penyusunan rencana kerja sampai dengan pelaksanaan ujian dari bulan Agustus sampai bulan Januari.

\section{Pengumpulan Data}

Pengumpulan data mengunakan teknik simple purposive sampling, dengan mengambil sampel dari populasi berdasarkan kriteria pertimbangan (judgment) tertentu (Jogiyanto, 2008).

\section{Analisis Data}

Penelitian ini menggunakan metode analisis deskriptif kualitatif, dengan cara melakukan interpretasi terhadap data, fakta dan informasi yang telah dikumpulkan melalui pemahaman intelektual yang dibangun atas dasar pengalaman empiris.

\section{HASIL DAN PEMBAHASAN}

\section{Sejarah}

Sejarah menunjukkan sebelum tahun 1428, rakyat Minahasa hidup berkelompok sehingga sering terjadi pertentangan antar kelompok bahkan sering mendapat gangguan dan rongrongan dari luar. Dengan pengalaman 
pahit dalam sejarah kehidupannya akibat dari kehidupan yang tidak bersatu itu, timbulah rasa persatuan dan kesatuan yang kokoh dan kuat dengan semangat menggelorakan "Minaesa atau Minahasa" yang berarti kehendak untuk bersatu. Minahasa yang dulunya disebut "Malesung" dan berkembang terus dengan sebutan Tanah Toar Lumimuut, Bumi Kawanua, Bumi Nyiur Melambai. Nama Minahasa berasal dari bahasa Tombulu yaitu : Wala Esa Ene, orang Tountemboan mengatakan Maesa, orang Tolour dan Tonsea mengatakan Minaesa, yang kemudian menjadi Minahasa.

Minahasa merayakan ulang tahunnya ditetapkan dalam satu dasar hukum oleh DPRD Tingkat II Minahasa pada tanggal 1 Oktober 1983 dengan Perda Nomor 8 Tahun 1983, yaitu tanggal 5 November sebagai tanggal simbolik hari lahirnya Pahlawan Nasional kelahiran Tanah Minahasa ialah DR. Sam Ratulangi, adalah hasil pemikiran dari tokoh-tokoh masyarakat daerah termasuk didalamnya adalah kaum cerdik pandai baik generasi muda, maupun generasi tua yang tergabung dalam Non Formal Leader dan Formal Leader di daerah Minahasa.

Pertumbuhan penduduk Minaha sa yang diikuti dengan penambahan desa dan kecamatan, maka pada tanggal 27 Februari 2003 melalui UU RI NO.10 Tahun 2003 Kabupaten Minahasa dimekarkan dan disahkan oleh pemerintah menjadi Kabupaten Minahasa Induk, Minahasa Selatan dan Kota Tomohon. Kemudian diakhir Tahun 2003 Minahasa Induk melalui UU No.33 Tahun 2003, dimekarkan lagi menjadi Minahasa Induk dan Minahasa Utara.

\section{Perkembangan Wilayah}

Minahasa Selatan adalah salah satu Kabupaten di Provinsi Sulawesi Utara. Ibukota dari Kabupaten Minahasa Selatan adalah Amurang, yang berjarak sekitar $\pm 66 \mathrm{~km}$ dari Kota Manado, Ibukota Provinsi Sulawesi
Utara. Letak geografis Kabupaten Minahasa Selatan berada pada posisi tengah Provinsi Sulawesi Utara, yang secara administratif terletak di sebelah selatan Kabupaten Minahasa dengan batas-batas wilayah sebagai berikut:

- Sebelah Utara berbatasan dengan Kabupaten Minahasa

- Sebelah Timur berbatasan dengan Kabupaten Minahasa Tenggara

- Sebelah Selatan berbatasan dengan Kabupaten Bolaang Mongondow

- Sebelah Barat berbatasan dengan Laut Sulawesi

Kabupaten Minahasa Selatan mempunyai topografi wilayah berupa bukit-bukit/pegunungan dan sebagian kecil adalah daratan rendah bergelombang dan memiliki sungai-sungai besar dengan posisi dari daerah pantai sampai ketinggian $1.500 \mathrm{~m}$ dari permukaan laut.

\section{Perkembangan Sumberdaya Pesisir}

Sumberdaya alam dalam ekosistem wilayah pesisir diperlukan dalam sub sektor perikanan sebagai salah satu pendorong pertumbuhan ekonomi. Jenis ekosistem yang dimaksud yaitu mangrove, padang lamun dan terumbu karang.

Mangrove hampir tersebar di sepanjang pantai Kabupaten Minahasa Selatan dengan bervariasi jenisnya. Hutan bakau (mangrove) adalah sebutan umum yang digunakan untuk menggambarkan suatu varietas komunitas pantai tropik yang didominasi oleh beberapa spesies pohon-pohon yang khas atau semak-semak yang mempunyai kemampuan untuk tumbuh dalam perairan asin. Merupakan tempat berlangsungnya kehidupan yang mencerminkan hubungan timbal balik antara makhluk hidup dengan lingkungannya dan diantara makhluk hidup itu sendiri, terdapat pada wilayah pesisir, terpengaruh pasang surut air laut, dan didominasi oleh spesies pohon atau semak yang khas dan mampu tumbuh dalam perairan asin/payau (Santoso dalam Rochana, 2002). 
Lamun yang juga sebagai habitat beberapa jenis ikan dan teripang serta penyu dan duyung. Padang lamun merupakan salah satu ekosistem yang terletak di daerah pesisir atau perairan laut dangkal. Lamun merupakan tumbuhan berbiji tunggal (monokotil) dari kelas Angiospermae (Syari, 2005). Perhatian terhadap ekosistem padang lamun (seagrass) masih sangat kurang dibandingkan terhadap ekosistem bakau (mangrove) dan terumbu karang (coral reefs). Padahal, lestarinya kawasan pesisir pantai bergantung pada pengelolaan yang sinergis dari ketiga ekosistem tersebut. Terlebih, padang lamun merupakan produsen primer organik tertinggi dibanding ekosistem laut dangkal lainnya (Syari, 2005).

Terumbu karang merupakan habitat bagi beberapa jenis biota laut dan sebagai tempat ikan-ikan mencari makan dan memijah, terumbuh karang juga memiliki fungsi sebagai pemecah ombak. Kabupaten Minahasa Selatan memiliki 36 jenis karang yang tersebar di pesisir Kabupaten Minahasa Selatan.

Terumbu karang memiliki produktifitas dan keanekaragaman yang tinggi. Terdapat banyak jenis karang batu yang di dalamnya hidup beraneka ragam biota perairan. Tipe terumbu karang yang ada umumnya adalah terumbu karang tepi (fringing reef) yang terletak sepanjang garis pantai. Pada beberapa lokasi juga dijumpai koloni terumbu karang yang mengelompok (patch reef) (Duran, 2008).

\section{Sumberdaya Manusia}

Berdasarkan struktur penduduk kelompok umur dan jenis kelamin, maka penduduk yang terbesar yang dilihat dalam kelompok umur 5-9 tahun dengan jumlah 19.669 jiwa dan jumlah penduduk terkecil dari kelompok umur 70-74 tahun dengan jumlah 4.185 jiwa. Perkembangan penduduk Kabupaten Minahasa Selatan tiap tahun terjadi penurunan, ini menunjukan bahwa masyarakat Minahasa Selatan sudah peduli dengan program pemerintah tentang keluarga berencana (KB).

\section{Sumberdaya Perikanan}

Masyarakat yang berada pada usaha perikanan laut di Kabupaten Minahasa Selatan terdiri dari pembudidaya ikan, nelayan, dan pengelolah hasil perikanan. Perkembangan masyarakat perikanan di Kabupaten Minahasa Selatan terjadi peningkatan dari tahun ke tahun. Hal ini terjadi karena adanya bantuan pemerintah terhadap sektor perikanan. Pada rumah tangga nelayan terjadi peningkatan yang sangat signifikan dari tahun 2009 ke tahun 2010 dengan jumlah perkembangan 5278 (RTP).

\section{Perikanan Tangkap}

Usaha penangkapan ikan merupakan suatu kegiatan yang dilakukan oleh masyarakat nelayan sebagai salah satu mata pencariannya. Usaha perikanan tangkap ini berkaitan pula dengan dengan upaya penangkapan ikan, baik yang berada di daratan (budidaya kolam dan tambak) maupun pembudidayaan ikan laut.

Nelayan Penangkap ikan di pesisir Kabupaten Minahasa Selatan menangkap ikan sepanjang pantai maupun di Laut Sulawesi. Kebanyakan nelayan tradisional hanya menangkap ikan sekitar 2-3 mil jauhnya dari pantai. Bagi nelayan purse sein (Soma Pajeko) cukup jauh dengan jarak 7-12 mill dari pantai. Ada beberapa alat tangkap yang digunakan oleh nelayan di Kabupaten Minahasa Selatan dengan pemakaian alat tangkap terbanyak pada pancing noru yang tersebar di seluruh kecamatan pesisir.

Armada Penangkapan sangat mempengaruhi produksi perikanan tangkap di Kabupaten Minahasa Selatan yang tersebar di tujuh kecamatan daerah pesisir. Dengan alat tangkap yang mendominasi adalah alat tangkap purse sein. Banyaknya nelayan menggunakan alat tangkap ini karena prinsip alat tangkap yang melingkari gerombolan-gerombolan ikan pelagis secara cepat. Pusat produksi Soma Pajeko diantaranya Kecamatan Amurang, Amurang Barat, Amurang 
Timur, Tatapaan dan Tumpaan. Lokasi penangkapan ikan di Kabupaten Minahasa Selatan biasanya pada Laut Sulawesi. Perkembangan produksi penangkapan di tiap tahunnya terjadi peningkatan, hal ini menunjukan ikan dilaut Sulawesi tidak mengalami over fising dan masih memproduksi banyak ikan dan jenis ikan yang terbanyak didapatkan dari perikanan tangkap adalah ikan cakalang.

\section{Budidaya Perikanan}

Budidaya laut sangat potensial untuk dikembangkan karena di dukung oleh wilayah laut dan pesisir Kabupaten Minahasa Selatan yang cukup luas dan potensial. Beberapa komoditi yang menjadi unggulan budidaya perikanan laut di Kabupaten Minahasa Selatan adalah budidaya rumput laut, budidaya ikan kerapu, budidaya ikan kuwe (bobara) dan budidaya teripang.

\section{Pengolahan Produk Perikanan}

Sifat alami ikan yang cepat rusak diperlukan penanganan dan pengolahan yang baik dan benar melalui proses pengolahan serta pengawetan ikan. Produksi olahan hasil perikanan di Kabupaten Minahasa Selatan sangat beragam baik yang di olah secara tradisonal maupun modern. Komoditas olah hasil perikanan itu berupa ikan kayu, ikan asin, ikan asap/fufu dan bakasang. Pemasaran hasil perikanan banyak di jual di pasar-pasar lokal saja, namun ada satu lokasi yang telah menjual hasil olahannya keluar negeri yaitu PT. Nichindo, dengan komoditas olahan adalah lkan kayu.

\section{Usaha Perikanan}

Produksi usaha perikanan di Kabupaten Minahasa Selatan dipengaruhi oleh beberapa jenis usaha perikanan yaitu usaha perikanan tangkap laut dan budidaya laut. Sektor penangkapan sangat banyak menyumbang produksi perikanan, pada tahun 2011 di peroleh 15.715 Ton hasil tangkapan. Usaha budidaya menyumbang 1.826 Ton.

\section{KESIMPULAN}

Dari hasil penelitian dapat disimpulkan beberapa hal penting yang berhubungan dengan pertumbuhan ekonomi dari sektor perikanan di daerah pesisir Kabupaten Minahasa Selatan sebagai berikut :

- Perkembangan sumberdaya pesisir di Kabupaten Minahasa Selatan terjadi pada 3 ekosisitem pesisir yaitu bakau (mangrove), lamun dan terumbu karang.

- Perkembangan sumberdaya manusia dari kependudukan terjadi penurunan setiap tahun yang menunjukan kepedulian terhadap program keluarga berencana.

- Perkembangan sumberdaya perikanan meningkat signifikan, dilihat dari jumlah Rumah Tangga Nelayan (RTP).

- Perkembangan perikanan tangkap terjadi peningkatan pada tiap tahunnya, khususnya penggunaan pancing noru untuk jenis ikan tangkapan ikan cakalang.

- Perkembangan budidaya yang menonjol adalah budidaya ikan kuwe (Bobara) dan Ikan Kerapu

- Perkembangan produk perikanan umumnya secara tradisional.

- Perkembangan usaha perikanan menunjukan kontribusi sektor perikanan terhadap perekonomian Kabupaten Minahasa Selatan terjadi peningkatan di tiap tahunnya.

\section{DAFTAR PUSTAKA}

De'e, R. 2010. Daya Saing Investasi Industri Perikanan di Kota Bitung: Persepsi Dunia Usaha dan Pemangku Kepentingan Terkait. Skripsi. Fakultas Perikanan dan Kelautan. Universitas Sam Ratulangi. Manado

Duran, S. S. 2008. Studi Potensi Sumberdaya dan Pengembangan Perikanan Kawasan Pesisir Kabupaten Minahasa Selatan Privinsi Sulawasi Utara. Tesis. 
Universitas Sam Ratulangi Program Pasca Sarjana. Manado Jogiyanto, H. M. 2008. Metodelogi Penelitian Sistim Informasi. Andi. Yogyakarta

Nurboko, C dan A. Achmadi. 2005. Metode Penelitian. PT Bumi Aksara. Jakarta
Rochana, E. 2002. Ekosistem Mangrove dan Pengelolaanya di Indonesia. Jakarta.

Syari, I. A. 2005. Asosiasi Gastropoda di Ekosistem Padang Lamun Perairan Pulau Lepar Provinsi Bangka Belitung. FPIK Institut Pertanian Bogor. Bogor 